DOI: https://doi.org/10.18371/fp.4(44).2021.344548

УДК: 339.7

\title{
СУТНІСТЬ ТА АНАЛІЗ ЗМІСТУ КЛЮЧОВИХ ЗАБОРОН В ІСЛАМСЬКІЙ ЕКОНОМІЧНІЙ ДОКТРИНІ
}

\author{
ЮРКЕВИЧ Оксана Миколаївна \\ к.е.н., дочент, \\ дочент кафедри корпоративних фінансів і контролінгу, \\ ДВНЗ «Київський національний економічний університет \\ імені Вадима Гетьмана» \\ ORCID ID: https://orcid.org/0000-0002-8172-0186
}

\begin{abstract}
Анотація. В основі ісламської економічної доктрини лежать релігійні заборони, які власне і визначають специфіку форм ісламських фінансових відносин та інструменти їх реалізаиії. Доктринальними заборонами $\epsilon$ piба, гарар, мейсір, харам. Згідно вимог ісламської юриспруденції можна змоделювати три типи економічних транзакцій, у двох з яких, згідно ісламської економічної доктрини, виникає ріба. Гарар є другим важливим елементом в системі заборон, які визначають специфіку ісламської економічної доктрини. Для визначення наявності в тій чи іншій угоді гарар, має бути не просто невизначеність, а невідомість. Майсір повністю відкидається ісламом, під яким розуміють дохід, якій є не результатом вкладання каnіталу або прачі, а щуо утворився в наслідок якоїсь випадковості. Категорія харам оперує двома поняттями - позитивне («дозволене», халяль) та негативне («заборонене», харам). Ісламська економічна доктрина визначає принципи, методи, форми та інструменти ведення економічної діяльності відповідно до релігійної етики, а ісламські фінанси - спосіб реалізащії фінансових відносин 3 метою отримання саме халяльного прибут$\kappa y$.
\end{abstract}

Ключові слова: ісламська економічна доктрина, ісламські фінанси, релігійна етика, ісламські економічні заборони, ріба, гарар, мейсір, харам.
Аннотация. В основе исламской экономической доктрины лежат религиозные запреты, которые и определяют специфику форм исламских финансовых отнотений и инструменты их реализации. Доктринальными запретами являются риба, гарар, мейсир, харам. Согласно требованиям исламской юриспруденции, можно смоделировать три типа экономических транзакций, в двух из которых возникает риба. Гарар является вторым важным элементом в системе запретов, определяющих специфику исламской экономической доктрины. Для определения наличия в той или иной сделке гарар должна быть не просто неопределенность, а неизвестность. Майсир полностью исключается исламом, под которым понимают доход, не как результат вложения капитала или труда, а образовавшийся вследствие какой-то случайности. Категория харам оперирует двумя понятиями - положительное («разрешенное», халяль) и отрищательное («запретное», харам). Исламская экономическая доктрина определяет принщипь, методы, формы и инструменты ведения экономической деятельности в соответствии с религиозной этикой, а исламские финансы - способ реализащии финансовых отношений с целью получения именно халяльной прибыли.

Ключевые слова: исламская экономическая доктрина, исламские финансы, религиозная этика, исламские экономические запреты, риба, гарар, мейсир, харам. 
Постановка проблеми. 3 другої половини XX століття в багатьох мусульманських країнах почався процес реісламізаціїі суспільства (так зване «ісламське відродження», або англ. Islamic revival).

Значною мірою цей процес було обумовлено розчаруванням світськими національними державами і прозахідними правлячими елітами, які домінували в мусульманському світі протягом попередніх десятиліть і які все частіше виявляли ознаки авторитарних, неефективних політичних систем, 3 відсутньою культурною автентичністю. Це була також реакція проти західного впливу та західних цінностей, таких як індивідуалізм, споживацтво, рівність прав жінок, сексуальна свобода, які розглядалися як підрив ісламських цінностей та ідентичності. Економічні та демографічні фактори, такі як відсталий економічний розвиток, зростання нерівності в доходах та зниження соціальної мобільності, розрив між очікуваннями та реальністю, зростання освіченої молоді 3 очікуванням кращих соціальних ліфтів та урбанізація в мусульманському світі також відігравали важливу роль.

У свою чергу, «ісламське відродження〉 обумовило виникнення та інституціалізацію нових форм соціально-економічних відносин на базі ісламської економічної доктрини - ісламських фінансів, які реалізуються за допомогою специфічних організаційних форм бізнесу або специфічних структурованих фінансових продуктів/інструментів. На сьогодні індустрія ісламських фінансів є об'єктивним явищем та складовим елементом глобальної фінансової системи, а для деяких мусульманських країн, таких як, наприклад, Бахрейн, Смен, Іран, Ка- тар, Малайзія, Саудівська Аравія, Судан цей тип фінансових відносин має системну важливість, охоплюючи від 25 до 40 \% місцевого фінансового сектору.

В основі ісламської економічної доктрини лежать певні релігійні заборони, які власне і визначають специфіку форм ісламських фінансових відносин та інструменти їх реалізації. Отже, систематизація та аналіз ключових заборон дозволять краще розуміти саму ісламську економічну доктрину в контексті певних економічних категорії додана вартість, прирощення капіталу у часі, ризик, невизначеність, спекуляція, що є важливою умовою для подальшого дослідження наукової проблематики іiі розвитку.

Аналіз останніх досліджень і публікацій. Сучасна економічна думка дослідження ісламської економічної доктрини представлена численними публікаціями ісламських економістів та юристів, які розглядають це явище передусім з точки зору обгрунтування переваг провадження релігійної етики в сферу економіки, обгрунтування дієвості ісламських економічних концептів в контексті формування умов для більш справедливого розподілу національного багатства, подолання бідності, зменшення випадків спекуляційної, експлуатаційної та не чесної поведінки економічних агентів.

Серед вітчизняних дослідників даної проблематики можна відмітити праці О.М. Мозгового, О.В. Субочева [1], щодо аналізу сутності доктрини ісламських фінансів; публікації О.М. Юркевич, В.П. Залізнюк, щодо дослідження історичних передумов виникнення ісламських фінансів [2] та чинників еволюції ісламської економічної доктрини [3], роботи В.В. Кор- 
нєєва [4] та C.I. Лихолета [5] щодо особливостей розвитку ісламської фінансової моделі та принципів структурування іiі фінансових інструментів. Ця робота продовжує низку зазначених публікацій, зосереджуючи увагу саме на аналізі економічного змісту ключових заборон в ісламській економічній доктрині.

Виокремлення невирішених раніше частин загальної проблеми. Джерелами теорії та методології icламської юриспруденції на якій власне i грунтується ісламська економічна доктрина є догматичні принципи релігійно-етичного підходу, в контексті дозволеного (благодія) та не дозволеного (гріх). Таким чином, переважна більшість праць, які присвячено ісламським заборонам в сфері економічної діяльності зроблено в рамках обгрунтування доцільності їх існування не тільки в контексті релігійноетичних настанов, але і 3 точки зору суспільної вигоди. Проте, на нашу думку, дослідження ключових заборон ісламської економічної доктрини в контексті їх економічного змісту дозволить більш точно визначити функціональні рамки їх застосування для структурування та моделювання релевантних ісламських контрактних форм при організації комерційної діяльності в парадигмі ісламської юриспруденції.

Мета статті. В основі ісламської економічної доктрини лежать певні заборони, які власне кажучи, і визначають специфіку іï функціонування. Основними 3 цих заборон є: ріба (позиковий відсоток), гарар (зайвий ризик та невизначеність), мейсір (азартна поведінка/спекуляція), харам (заборона ведення певних видів бізнесу). Метою даної статті, за допомогою методів систематизації та узагальнення, $€$ дослідження ключових заборон ісламської економічної доктрини в контексті їх економічного змісту. Відповідно, об’єктом дослідження є процеси розвитку ісламської економічної системи в умовах глобалізації. Предметом дослідження $\epsilon$ концептуально-методологічні принципи ісламської релігійної етики та іï вплив на формування базових засад ісламської економічної доктрини.

Виклад основного матеріалу. Icламська економічна доктрина виникла в середині VII ст. і повністю грунтується на релігійній етиці ісламу. Друга хвиля розвитку специфічних та властивих мусульманським країнам організаційних форм бізнесу та структурованих фінансових продуктів / інструментів почалась приблизно 3 другої половини $\mathrm{XX}$ століття, 3 початком процесу реісламізації в багатьох країнах Близького Сходу. Доктринальними заборонами є ріба, гарар, мейсір, харам.

Ріба. Слово «ріба» (в бук. перекладі 3 арабського - «прирощення»), вживалося арабами ще до ісламу для позначення поняття «збільшення». Сьогодні слово має значення лихварства та позичкового відсотку, позначає додаткове/надлишкове зростання/збільшення i $\epsilon$ основним 3 усіх елементів ісламських фінансів. У класичній ісламській юриспруденції визначенням ріба $\epsilon$ «надлишкова вартість за відсутністю невід'ємної частини що забезпечує утворення цієї вартості» [6].

Ріба в угоді, як правило, класифікується за двома основними характеристиками: ріба ал-насі'a (Ribā al-Nasīah) та ріба ал-фадл (Ribā al-Fadhl). Ріба алнасі'а відбувається при відтермінуванні розрахунку в часі і може означати надбавку до основної суми боргу, 
яка виплачується в обмін на відстрочку платежу. Цей вид ріба присутній у кредитному договорі і означає будьяку надбавку до основної суми боргу, що отримується позикодавцем в якості однієї з умов надання коштів в борг на певний термін. Ріба ал-фадл відбувається при продажі 3 надлишком або надлишком, що стягується при обміні певного товару. Цей вид ріба має місце при бартерному обміні партії одно- го і того ж товару на іншу, більш низької якості або в нерівній пропорції $[7,8,9]$. В наші дні набула поширення інша, більш проста класифікація ріба: позичкова ріба - ал-дуйун (Riba alDuyun) i торговельна ріба - ал-буйу' (Riba Buyu'). Позичкова ріба включає в себе дві форми ріба ал-насі'а. До торговельної ріба відносяться як ріба аннасі’а, так і ріба ал-фадл (табл. 1).

Види Ріба та її застосування.

\begin{tabular}{|c|c|c|c|c|c|}
\hline \multirow{2}{*}{ Типи ріба } & \multirow{2}{*}{ Визначення } & \multirow{2}{*}{$\begin{array}{c}\text { Підтипи } \\
\text { ріба }\end{array}$} & \multirow{2}{*}{ Визначення } & \multicolumn{2}{|c|}{$\begin{array}{c}\text { Позичкова ріба складається } 3 \\
\text { двох форм ріба ал-насі’a }\end{array}$} \\
\hline & & & & $\begin{array}{l}\text { Ріба ал- } \\
\text { кур'ан }\end{array}$ & $\begin{array}{c}\text { Ріба ал- } \\
\text { джахілі’a }\end{array}$ \\
\hline $\begin{array}{c}\text { Ріба ал-дуйун } \\
\text { (позичкова) }\end{array}$ & $\begin{array}{c}\text { Приріст понад } \\
\text { основної суми, } \\
\text { грошей (або } \\
\text { інших грошових } \\
\text { цінностей) по- } \\
\text { зичених в гро- } \\
\text { шовій або нату- } \\
\text { ральній формі }\end{array}$ & $\begin{array}{l}\text { Ріба ал- } \\
\text { насі'а }\end{array}$ & $\begin{array}{c}\text { Відбувається при } \\
\text { відтермінуванні } \\
\text { розрахунку в часі } \\
\text { (extension of time, } \\
\text { delay) }\end{array}$ & $\begin{array}{c}\text { Лихварський } \\
\text { кредит, зга- } \\
\text { даний у Ко- } \\
\text { рані, } є \text { фор- } \\
\text { мою Ріба-ал- } \\
\text { Кур'ан }\end{array}$ & $\begin{array}{c}\text { Збільшення } \\
\text { грошей внаслі- } \\
\text { док стягування } \\
\text { з позичальника } \\
\text { за несвоєчасне } \\
\text { погашення або } \\
\text { неповернення } \\
\text { фінансової по- } \\
\text { зики } \\
\end{array}$ \\
\hline \multirow[t]{2}{*}{$\begin{array}{l}\text { Ріба ал-буйу } \\
\text { (торгівельна) }\end{array}$} & \multirow{2}{*}{$\begin{array}{c}\text { Відбувається в } \\
\text { торгових та бір- } \\
\text { жових операці- } \\
\text { ях, в яких існує } \\
\text { нерівноцінний } \\
\text { обмін певними } \\
\text { товарами одна- } \\
\text { кового типу }\end{array}$} & $\begin{array}{l}\text { Ріба ал- } \\
\text { фадл }\end{array}$ & $\begin{array}{c}\text { Відбувається при } \\
\text { продажі з надли- } \\
\text { шком або надли- } \\
\text { шком, що стягу- } \\
\text { ється при обміні } \\
\text { певного товару } \\
\text { (surplus in ex- } \\
\text { change) }\end{array}$ & \multicolumn{2}{|c|}{$\begin{array}{c}\text { Через неоднакову кількість / } \\
\text { обсяг }\end{array}$} \\
\hline & & $\begin{array}{l}\text { Ріба ал- } \\
\text { насі’а }\end{array}$ & $\begin{array}{c}\text { Відбувається при } \\
\text { відтермінуванні в } \\
\text { часі обміну зу- } \\
\text { стрічними ціннос- } \\
\text { тями (extension of } \\
\text { time, delay) }\end{array}$ & \multicolumn{2}{|c|}{$\begin{array}{c}\text { Завдяки продовженню строку } \\
\text { поставки товару }\end{array}$} \\
\hline
\end{tabular}

Джерело: складено автором за даними $[7,8,9]$.

При цьому, в ісламській економічній доктрині існує важливе правило для ідентифікації ріба при створенні доданої вартості. Це стосується, як заборони відтермінування розрахунку в часі (extension of time, delay), так й заборони обміну з надлишком (surplus in exchange). Дане правило розповсю- джуються тільки на ті економічні транзакції, в яких присутні еквівалентні, за своєю економічною природою, предмети (активи) такої угоди, наприклад: $\mathrm{T} \leftrightarrow$ Т $\Delta$ (товар - товар) або $\Gamma \leftrightarrow$ $\Gamma \Delta$ (гроші - гроші). За умов використання грошей в якості засобу опосередкування будь-якої товарної економі- 
чної транзакції (функція грошей як засіб обігу), тобто: $\Gamma \leftrightarrow \mathrm{T} \Delta$ (гроші товар), дані заборони у вигляді ріба не виникають.

Філософські корені цього правила, яке з часом увійшло у всі Авраамічні релігії на ранніх етапах їх розвитку, безпосередньо пов'язані 3 думками філософів стародавнього світу, перш за все, Ксенофонтом, Платоном, Аристотелем. Вони вважали, що єдине призначення грошей, це - опосередкову- вати торгівлю (як засіб обміну без внутрішньої вартості), тому створення багатства 3 обігу самих грошей (надавати їх у борг) не $\epsilon$ продуктивною діяльністю, а отже й не може бути схвалено суспільством.

Таким чином, $з$ огляду на таблицю 1, можна змоделювати три типи економічних транзакцій, у двох 3 яких, згідно ісламської економічної доктрини, виникає ріба (табл. 2).

Таблиця 2

Виникнення ріба в угоді, згідно ісламської економічної доктрини.

\begin{tabular}{|c|c|c|c|c|c|}
\hline \multicolumn{2}{|c|}{ I тип } & \multicolumn{2}{|c|}{ II тип ріба } & \multicolumn{2}{|c|}{ III тип ріба } \\
\hline \multicolumn{2}{|c|}{$\begin{array}{c}(1.1) \mathbf{T} \leftrightarrow \boldsymbol{\Gamma} \\
\text { (товар } \leftrightarrow \text { гроші) }\end{array}$} & \multicolumn{2}{|c|}{$\begin{array}{c}(2.1) \Gamma \leftrightarrow \Gamma \\
\text { (гроші } \leftrightarrow \text { гроші) }\end{array}$} & \multicolumn{2}{|c|}{$\begin{array}{c}(3.1) \Gamma^{1} \leftrightarrow \Gamma^{2} \\
(\text { гроші } \leftrightarrow \text { інші гроші) }\end{array}$} \\
\hline час & маржа & час & маржа & час & маржа \\
\hline \multirow[t]{4}{*}{ дозволено } & дозволено & заборонено & заборонено & заборонено & дозволено \\
\hline & & \multicolumn{2}{|c|}{$\begin{array}{c}(2.2) \mathbf{T} \leftrightarrow \mathbf{T} \\
\text { (товар } \leftrightarrow \text { товар) }\end{array}$} & \multicolumn{2}{|c|}{$\begin{array}{c}(3.2) \mathbf{T}^{\mathbf{1}} \leftrightarrow \mathbf{T}^{\mathbf{2}} \\
\text { (товар } \leftrightarrow \text { інший товар) }\end{array}$} \\
\hline & & час & маржа & час & маржа \\
\hline & & заборонено & заборонено & заборонено & дозволено \\
\hline
\end{tabular}

Джерело: складено автором

I тип: в угодах продажу товару за гроші (при звичайних грошових розрахунках) дозволяється, як націнка (у вигляді створення додаткової вартості), так й відстрочка платежу за придбаний товар. При цьому вони узгоджується з ісламським правом i, 3 цієї точки зору, не є забороненими.

II тип: в угодах, предметом яких $\epsilon$ обмін однорідними активами, наприклад, гроші ↔ гроші, або товар $\leftrightarrow$ товар, виникає piбa, як в частині націнки, так й відстрочки платежів. Отже, з точки зору ісламського права, вони є забороненими.

III тип: в угодах, предметом яких $\epsilon$ обмін не однорідними активами, наприклад, гроші ↔ інші гроші (інші валюти), або товар $\leftrightarrow$ інший товар, дозволяється включати додану вартість, проте забороняється відтермінування їх виконання/закриття. Тобто, з точки зору ісламського права, таки угоди не $\epsilon$ ріба лише на умовах виконання «спот». Проблема заборони лихварства $\epsilon$ ключовою для розуміння сутності ісламської економічної доктрини. I хоча всі три авраамістичні релігії (іудаїзм, християнство та іслам) протягом свого існування, в тій чи іншій мірі, засуджували стягування i надання позичкового відсотка, однак лише мусульманське суспільство зберегло його послідовне неприйняття до сучасних часів. В той же час, громадські системи, в яких привалює іудаїзм або християнство, поетапно прийшли до фактичної легалізації багатьох операцій, які вважалися раніше лихварськими. 
Сьогодні у світі у правовому полі переважної більшості розвинених країн термін «лихварство» законодавчо не визначається і не використовується; розмір відсоткової ставки встановлюється залежно від умов що склалися на кредитному ринку, а порядок сплати самих відсотків - на договірної основі. Сдине що є предметом правового регулювання, це розмір відсоткової ставки яку кредитор має нараховувати боржнику після спливу строку позики на несплачену частину боргу.

До таких країн, власне кажучи, належить Україна. По-перше, сплачуваний боржником відсоток понад основної суми визначається, за своєю правовою природою, як винагорода за користування грошовими коштами протягом певного періоду (ст.536 Цивільного кодексу України). По-друге, згідно Цивільного кодексу України (ст.536, ст.1048, ст.1054, ст.1056) розмір і порядок одержання процентів встановлюються договором «залежно від кредитного ризику, наданого забезпечення, попиту і пропозицій, які склалися на кредитному ринку, строку користування кредитом, розміру облікової ставки та інших факторів, що діють на дату укладення договору» [10]. I нарешті, по-третє, вітчизняна судова практика (згідно Ч. 2 ст. 625 Цивільного кодексу України) встановлює, що «боржник, який прострочив виконання грошового зобов'язання, зобов'язаний сплатити суму боргу 3 урахуванням встановленого індексу інфляції за весь час прострочення, а також $3 \%$ річних від простроченої суми, якщо інший розмір процентів не встановлений договором або законом» [10].

Однак, у світі також є країни, які на законодавчому рівні обмежують відсоткову ставку кредитних угод. Наприклад, Кримінальний кодекс Канади обмежує іiі на рівні $60 \%$ на рік, а відповідно до цивільного законодавства Японії, максимальна відсоткова ставка становить від $15 \%$ до $20 \%$ на рік, залежно від основної суми боргу (більші суми мають нижчу межу дозволеної ставки) [11]. Проте, на нашу думку, законодавче обмеження розміру кредитних ставок не вирішує проблеми доступу до фінансових ресурсів або незахищеності прав позичальників.

У сучасному розумінні лихварське кредитування, яке пов'язано 3 наданням споживчих позик за завищеними відсотковими ставками отримало назву «хижацьке кредитування» (англ.: predatory lending, loan shark). Такий вид кредитування має жорсткі умови стягнення в разі неповернення кредиту i, як правило, діє поза межами закону (має кримінальний або напівкримінальний характер). Позичальниками $є$ особи, які не мають змоги отримати офіційний кредит у фінансовій установі, в силу тих чи інших причин. Отже, розвиток фінансового сектору та спрощення доступу до фінансових послуг вразливих верств населення, на нашу думку, $є$ більш ефективним шляхом вирішення проблеми існування лихварства, ніж встановлення правових обмежень щодо регулювання відсоткових ставок на кредитному ринку.

Гарар. Гарар є другим важливим елементом в системі заборон, які визначають специфіку ісламської економічної доктрини і у буквальному перекладі 3 арабського означає «небезпеку, ризик, невизначеність». У правовій площині, гагар означає «ро- 
бити щось наосліп, не маючи достатніх знань», або «зважитися на ризикований вчинок, не оцінюючи наслідки». Метою цієї заборони є уникнення обману та захист прав договірних сторін угоди, а також мінімізація суперечок та зменшення можливостей для використання одного контрагента іншим 3 спричиненням економічних втрат [12].

В ісламській економічній доктрині, сформульованої на базі релігійноетичних принципів, значна увага приділяється поняттю «справедливість», яке в деяких випадках навіть переважає поняття «правова норма».

Для ілюстрації ситуації з наявністю гарар, можна привести відому російську казку «Вершки и Корешки», яка окреслює поле для дискусії - що є більш важливим, «справедливість» чи «правова норма»? Згідно фабули цієї казки, одна з сторін договору (про розподіл врожаю) не володіла вичерпною інформацією про предмет розподілу (вершки/корешки). Формально, угоди між сторонами були укладені 3 дотриманням усіх необхідних умов, проте 3 точки зору ісламського права, вони не мають юридичних наслідків, оскільки містять гарар, а саме - невизначеність для одній 3 сторін щодо саме предмету договору. При цьому, гарар у даному випадку має надмірний характер, оскільки дає змогу одній із сторін збагачуватися за рахунок іншої, яка не володіє всією повнотою інформації про предмет договору.

Від самого початку мусульманське право виникало і розвивалося, перш за все як право, що регулювало торгівельні відносини. Тому наявність в ньому обмежень щодо «несправедливого» переважання в угоді однієї сторони над іншою в наслідок не- визначеності, за відсутності ефективних правових інститутів грало важливу роль у правовому забезпеченні торгівельно-обмінних операцій тих часів.

В двох головних джерелах ісламського права - Корані і суннах немає чіткого визначення поняття «гарар». Разом 3 тим існує багато хадісів, в яких докладно викладаються деякі правила торгівлі, у тому числі ті, де забороняється невизначеність у відношеннях між покупцем та продавцем. Наприклад, забороняється продавати те, що не знаходиться в момент заключення угоди в наявності у продавця: «Не купуйте рибу в морі, тому що в такій угоді $\epsilon$ невизначеність» [Цит. по: Ібн Хаджар Аль-Аскалані], [13].

Очевидно, що будь-якому виду підприємницької діяльності властиві ризик та невизначеність, тому на відміну від ріба, гарар $є$ відносною концепцією. Проте, одна справа неминучий комерційний ризик, інша справа - угоди, в результаті яких хоча 6 одна 3 сторін приймає на себе невиправданий ризик i може в наслідок цього понести втрати.

Деякі дослідники диференціюють терміни «невизначеність» та «ризик», оскільки ризик описується як ситуація, в якій можна виміряти ймовірність настання події. Отже, цей ризик можна оцінити теоретично [14]. Якщо розглядати гарар як надмірний ризик, то оцінка його надмірності $\epsilon$ виключною компетенцією мусульманських правознавців, які у сучасній практиці інституалізуються в додатковий виконавчий орган управління компанією - Шаріатську раду.

Правознавці усіх ісламських юридичних шкіл (мазгабів) мають консен- 
сус 3 приводу того, що наявність надмірного гарар у договорі лишає його законної сили і може зробити не дійсним 3 точки зору ісламського права.

У відповідності з загальноприйнятою у сучасному ісламському праві класифікацією,

виокремлюють наступні види (або ступені) гарар:

- дозволений / незначний гарар (gharar yasīr, minor gharar), не впливає на валідність угоди;
- заборонений / зайвий гарар (gharar fahish, major або excessive gharar), перетворює будь-яку угоду у недійсну;

В деяких ісламських правових школах виокремлюють також проміжний гарар, який знаходиться між двома першими, але 3 точки зору правових наслідків він не класифікується як окрема категорія. Приклади трактування цього терміну наведено в табл. 3 .

Таблиця 3

Визначення гарар різними ісламськими правовими школами

\begin{tabular}{|l|l|}
\hline Правова школа & \multicolumn{1}{c|}{ Визначення } \\
\hline Ханафітська & «гарар це те, наслідки чого приховані» (Al-Sarakhsi) \\
\hline Шафіїтська & «гарар» це те, чия природа та наслідки приховані» (Al-Shıraazı) \\
\hline Ханбалітська & «гарар це те, наслідки чого невідомі» (Ibn Taymiya) \\
\hline
\end{tabular}

Джерело: складено автором на основі [15]

Найбільш ліберальне трактування поняттю «гарар» було надано представниками зниклого ще у Середньовіччі (XV ст.) загірітського мазгабу, який був широко розповсюджений на території Північної Африки та мусульманської Іспанії. За думкою представників цієї правової школи, для визначення наявності в тій чи іншій угоді гарар, має бути не просто невизначеність, а невідомість, тобто «покупець не знає що він купує, а продавець не знає що він продає».

Саме цей підхід щодо визначення гарар, на нашу думку, покладено в основу сучасної практики ісламських фінансів, в яких заборонений гарар має місце коли існує невпевненість щодо: а) об'єкту угоди; б) його ціни:

- об'єкт угоди ще не існує (або сумніви щодо його наявності);

- відсутне точне і детальне описання об'єкту угоди с точки зору його кількості та якості (або сумніви щодо достовірності інформації);
- відсутні фіксована ціна, термін та умови оплати (або залежність цих категорій угоди від других обставин, наявність двох цін за певних умов, залежність умов виконання від інших подій).

Проте, економічна доцільність змушує визнавати легітимною, 3 точки зору ісламського права, таку угоду як бай'ас-салам (або салам) - купівляпродаж товарів 3 відстроченою поставкою, коли покупна ціна сплачується відразу, а товар поставляється протягом терміну, узгодженого сторонами (рис. 1). Предметом цієї угоди, в основному є рухоме майно яке можна оцінити за якістю та кількістю (окрім дорогоцінних металів та грошей) або нерухомість (наприклад, у випадку фінансування будівництва). Не зважаючи, все ж таки, на наявність певної невизначеності для покупця, салам признано допустимою угодою 3 дозволеним рівням гарар. 


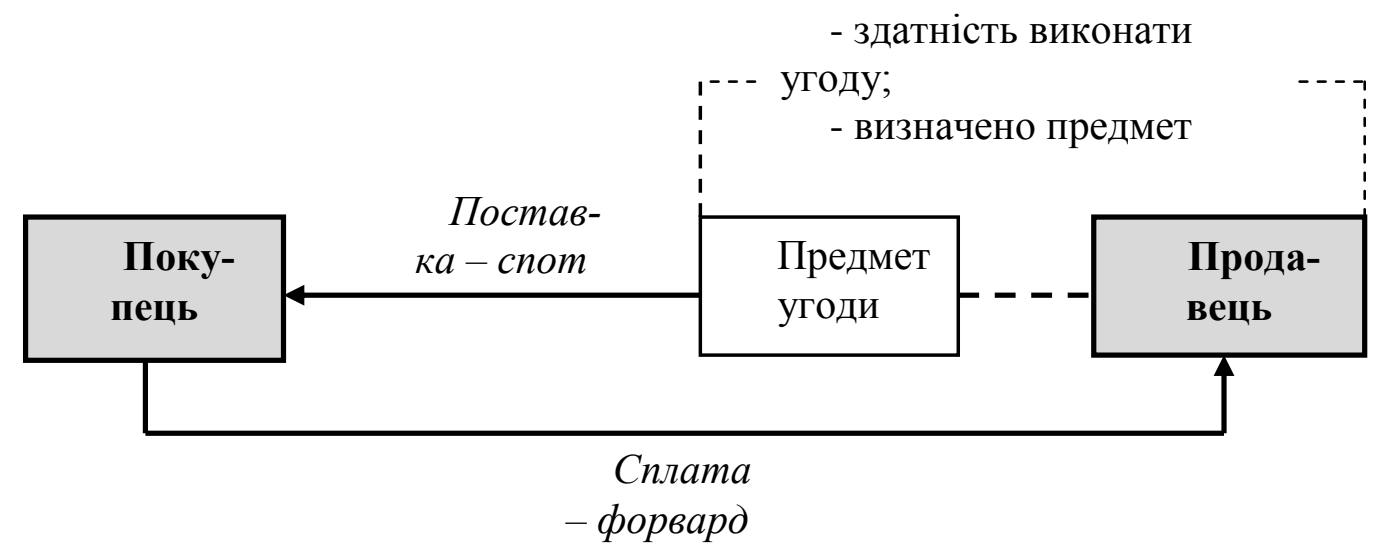

Рис.1. Угода бай’ас-салам (або салам).

Однак, оцінка угоди щодо наявності в неї забороненого гарар, відноситься до виключної компетенції мусульманських правознавців - членів Шаріатської ради банку або іншого фінансового інституту.

Майсір. На відміну від гарар, майсір повністю відкидається ісламом (див., наприклад: Коран: 2:212; 5:90; 5:91), при чому його заборона цитується в тих аятах Корану, де встановлено також заборону для мусульман на вживання алкоголю. Даний термін походить від слова арабського слова «легкий» і буквально означає «легкодоступне багатство» або «азартну гру», або також позначає випадкове набуття багатства/доходу без вкладання праці/ресурсів, незалежно від того, завдано було чи ні шкоди іній людині. В той же час, деякі дослідники наполягають, що мають бути сторони, кожна 3 яких бере на себе ризик втрати, а втрата однієї означає виграш іншої [16]. В ісламської економічної доктрини, найчастіше даним терміном називають будь-які азартні ігри («будьяка операція, здійснена двома сторонами, що володіють правом власності на певний актив або послугу, які приносять користь одній стороні та завдають шкоди іншій, пов'язуючи кон- кретну операцію з діянням чи подією, метою яких є заволодіння майном іншого учасника» $[17,18])$, включаючи ставки, лотерею тощо.

Тобто, мусульманські економісти розуміють під мейсір дохід, якій $\epsilon$ не результатом вкладання капіталу або праці, а що утворився в наслідок якоїсь випадковості. Для того, щоб вважатися азартною грою, принаймні мають бути три елементи:

- існування предмета / активу ставок з обох сторін;

- існування самої гри, за допомогою якої визначають, хто переможе, а хто програє;

- переможець отримує майно (частину / ціле), на яке зроблена ставка, а той хто програв - втратить його.

Данні елементи, в контексті мейсір, можуть бути повністю застосованими в якості обмежень на велику кількість видів фінансових операцій та інструментів фондового ринку. Мова йдеться про спекуляційні операції, а також про похідні цінні папери пов'язані 3 хеджуванням ризику.

Деякі мусульманські економісти навіть вважають спекуляції та азартні ігри синонімами. Проте, переважна їх більшість все-таки диференціює ці поняття в рамках ісламського права, 
аргументуючи тим, що в азартній грі, ризик є iї метою і виникає сам по собі (з самої гри), а транзакції на фондовому ринку здійснюються на основі внутрішньої вартості активів 3 урахуванням їх поточної ринкової вартості (тимчасових відхилень від їх «справедливої» ціни) [19]. Тому, як вони вважають, ці поняття не є тотожними, а спекуляція не підпадає під обмеження мейсір. Крім того, дуже важко розмежувати фондові операції «спекуляційні» (несуть, як правило, негативну конотацію) та операції «інвестиційні», в основі яких лежить аналіз очікуваної доходності та ризику.

Що стосується ісламських фінансових деривативів, специфіка та особливості їх інжинірингу будуть розглянуті більш детально у наступних дослідженнях.

Як гарар, так i мейсір пов'язані 3 невизначеністю та ризиком, проте відмінність між ними в тому, що перший $є$ результатом непрозорості умов реалізації угоди, а другий ставить очікуваний дохід/збиток в залежність від настання/ненастання певної події у майбутньому (випадковість).

Харам. Ще одна релігійна заборона яка визначає специфіку ісламської економічної доктрини - харам (в ісламському праві недозволені речі й діiі). Для мусульман існують обмеження у сімейно-шлюбних стосунках, у вживанні їжі та напоїв, в розвагах, у поведінці протягом релігійного посту. В контексті економічної діяльності харам забороняє займатися, інвестувати або отримувати доходи 3 певних видів бізнесу, таких як, наприклад: виробництво алкогольних напоїв, тютюну та свинини, організація азартних ігор, деякі сфери шоу-бізнесу та розваг тощо,
Категорія харам займає важливе місце у формуванні ісламської етики, яка оперує двома поняттями - позитивне («дозволене», халяль) та негативне («заборонене», харам). Мусульманин, як у своєму повсякденному житті, так і в економічній діяльності має приймати рішення і діяти таким чином, щоб не порушувати рамки «халяльхарам». Власне кажучи, ісламська економічна доктрина, як феномен, визначає принципи, методи, форми та інструменти ведення економічної діяльності у відповідності до релігійної етики, а ісламські фінанси, відповідно, це спосіб реалізації фінансових відносин 3 метою отримання саме халяльного прибутку.

Висновки. Таким чином, досліджені нами заборони в ісламській економічній доктрині визначають специфічні форми фінансових відносин та інструменти їх реалізації, які формуються під впливом релігійних вимог.

Згідно вимог ісламської юриспруденції можна змоделювати три типи економічних транзакцій, у двох 3 яких, згідно ісламської економічної доктрини, виникає ріба: I тип: в угодах продажу товару за гроші (при звичайних грошових розрахунках) дозволяється, як націнка (у вигляді створення додаткової вартості), так й відстрочка платежу за придбаний товар; II тип: в угодах, предметом яких $\epsilon$ обмін однорідними активами, наприклад, гроші $\leftrightarrow$ гроші, або товар $\leftrightarrow$ товар, виникає ріба, як в частині націнки, так й відстрочки платежів; III тип: в угодах, предметом яких $є$ обмін не однорідними активами, наприклад, гроші $\leftrightarrow$ інші гроші (інші валюти), або товар $\leftrightarrow$ інший товар, дозволяється включати додану вартість, проте забороняється 


відтермінування
ня/закриття.

Гарар є другим важливим елементом в системі заборон, які визначають специфіку ісламської економічної доктрини. У правовій площині, гагар означає «робити щось наосліп, не маючи достатніх знань», або «зважитися на ризикований вчинок, не оцінюючи наслідки». Найбільш ліберальне трактування поняттю «гарар» було надано представниками загірітського мазгабу, за думкою представників якого, для визначення наявності в тій чи іншій угоді гарар, має бути не просто невизначеність, а невідомість, тобто «покупець не знає що він купує, а продавець не знає що він продає». Саме цей підхід щодо визначення гарар, на нашу думку, покладено в основу сучасної практики ісламських фінансів, в яких заборонений гарар має місце коли існує невпевненість щодо: об'єкту угоди; б) його ціни.

Майсір повністю відкидається ісламом, під яким розуміють дохід, якій $\epsilon$ не результатом вкладання капіталу або праці, а що утворився в наслідок якоїсь випадковості. Для того, щоб вва- жатися азартною грою, принаймні мають бути три елементи: існування предмета / активу ставок з обох сторін; існування самої гри, за допомогою якої визначають, хто переможе, а хто програє; переможець отримує майно (частину / ціле), на яке зроблена ставка, а той хто програв - втратить його. Данні елементи, в контексті мейсір, можуть бути повністю застосованими в якості обмежень на велику кількість видів фінансових операцій та інструментів фондового ринку. Мова йдеться про спекуляційні операції, а також про похідні цінні папери пов'язані з хеджуванням ризику.

Категорія харам займає важливе місце у формуванні ісламської етики, яка оперує двома поняттями - позитивне («дозволене», халяль) та негативне («заборонене», харам). Власне кажучи, ісламська економічна доктрина, як феномен, визначає принципи, методи, форми та інструменти ведення економічної діяльності у відповідності до релігійної етики, а ісламські фінанси, відповідно, це спосіб реалізації фінансових відносин 3 метою отримання саме халяльного прибутку.

\section{Список використаної літератури}

1. Мозговой О.М., Юркевич О.М., Субочев О.В. Сутність та розвиток доктрини ісламських фінансів. Економіка Украӥни. 2018. № 1 (674). С. 71-82.

2. Юркевич О.М., Залізнюк В.П., Субочев О.В. Історичні передумови виникнення ісламських фінансів як складового сегменту сучасної міжнародної фінансової системи. Інвестииії: практика та досвід. 2021. № 15. С. 12 - 18. URL: http://www.investplan.com.ua/pdf/15_2021/4.pdf

3. Юркевич О. М., Залізнюк В. П., Субочев О. В. Чинники еволюції ісламської економічної доктрини в контексті розвитку міжнародних фінансів. Економіка та держава. 2021. № 8. C. 73-78. URL: http://www.economy.in.ua/pdf/8_2021/14.pdf

4. Корнєєв В.В. Ісламська фінансова модель: особливості розвитку. Вісник сочіально-економічних досліджень. 2012. Вип. 1 (44).C. 312-318. URL: http://vsed.oneu.edu.ua/files/full/1_44_2012/312-318.pdf 
5. Юркевич О. М., Субочев О. В., Лихолет С. І. Структуровані фінанси як окремий елемент глобальної фінансової системи. Економіка та держава. 2020. № 11. C. $47-53$.

6. Investment Laws in Muslim Countries. Handbook, Volume 1. Investment Laws, Regulations and Opportunities in Selected Countries. 6th Edition. Int'l Business Publications. 2015. p. 23.

7. Ibn al-Qayyim al-Jawziyyah, Muhammad ibn Ab̄i Bakr. (1999). I'lām alMuwaqi' ìn 'an Rab al- 'Älamīn, Vol. 3. Cairo: Maktabah Ibn Taimiyyah.

8. Al-Shirbīn̄i, Syamsuddīin Muhammad ibn Muhammad al-Khatīb. (2006). Mughni al-Muhtāj ilā Ma'rifati Ma'ān̄̄ Alfāzi al-Minhāj, Vol. 2. Cairo: Dār alHadith.

9. Ahmad, Taris et al. (2010). Islamic Banking and Finance: What It Is and What It Should Be, UK: 1st Etichal Charitable Trust.

10. Цивільний кодекс України. URL: https://zakon.rada.gov.ua/laws/show/43515\#Техt (дата звернення: 30.11.2021)

11. PART XV. Special Procedure and Powers (continued). Criminal Code (R.S.C., 1985, c. C-46). URL: https://laws-lois.justice.gc.ca/eng/acts/c-46/page-77.html\#h122004 (дата звернення: 30.11.2021)

12. Muhammad Iman Sastra Mihajat. Contemporary Practice of Riba, Gharar and Maysir in Islamic Banking and Finance. IIUM Institute of Islamic Banking and Finance. International Journal of Islamic Management and Business. 2016. Vol. 2, No. 2, 1. URL: http://www.crimbbd.org/wp-content/uploads/2015/01/Contenporarypractice-of-Riba-Gharar-and-Mysir-in-IBS-Fs.pdf (дата звернення: 30.11.2021)

13. Булуг ал-Марам. Достижение цели в уяснении священных текстов, на которые опирается мусульманское право. Исламские финансы в современном мире: экономические и правовые аспекты/ под ред. Р.И. Беккина. М., 2004. С. 246.

14. Kamali, M. H. Uncertainty and Risk Taking (Gharar) in Islamic Law. International Journal of Islamic Management and Business. 2016. Vol. 2, No. 2.

15. Al-Zuhayli, Dr. Wahbah (1997), Financial Transactions in Islamic Jurisprudence: Revised Edition, Gharar, vol. 5, pp. 2408-3411, Syria: Dar al-Fikr Damascus, Syria, Dar al-Fikr al-Mouaser.

16. Al-Misri, Rafiq Yunus. (1993). Al-Maysir wa al-Qimar al-Musābaqaāt wa alJawāiz, Damascus.

17. Antonio, M. S. Shariah bank: from theory to practice. Jakarta : Gema Insani Press, 2001.

18. Ayub, Muhammad. Understanding Islamic Finance. England: John Wiley \& Sons Ltd, 2007.

19. Kamali, M. H. Fiqhi Issues in Commodity Futures in "Financial Engineering and Islamic Contracts. New York: Palgraves, 2005. p. 20-57. 